\title{
Glucagon-like peptide-1 secretagogues from the leaves of Oparanthus teikiteetinii
}

\author{
Huguet Clement ${ }^{1}$, Olatunji Opeyemi Joshua ${ }^{1,4}$, Real Eleonore ${ }^{2}$, Raharivelomanana Phila ${ }^{3}$,
} Urbain Aurélie ${ }^{1, *}$

1 Univ Strasbourg, CNRS, IPHC UMR 7178, F-67000 Strasbourg, France.

2 Univ Strasbourg, CNRS, LBP UMR 7021, F-67000 Strasbourg, France.

3 Univ Polynesie Francaise, EIMS UMR 241 EIO, F-98702 Faaa Tahiti, French Polynesi, France.

${ }^{4}$ Prince Songkla Univ, Fac Tradit Thai Med, Hat Yai 90112, Thailand.

* Corresponding author : Aurélie Urbain, email address : urbain@unistra.fr

\begin{abstract}
:
In our search for natural compounds that stimulate glucagon-like peptide-1 secretion, an extract from the leaves of Oparanthus teikiteetinii (Asteraceae) was found to increase significantly GLP-1 secretion in vitro in a model cell line (mouse intestinal STC-1 cells). The phytochemical investigation of this extract resulted in the isolation of two new dihydrobenzofuran derivatives (1-2) identified as (2R)-2-(prop-1-en-2-yl)-2,3dihydro-1-benzofuran-5-ol (1) and (2S,3R)-2-(prop-1-en-2-yl)-2,3-dihydro-1-benzofuran-3,5-diol (2). Thirteen other compounds were isolated, including eight known dihydrobenzofuran derivatives (3-10), jasopyran (11), and four sesquiterpene lactones (12-15) including a new one, grandulin (15). Their structures were established mainly by NMR and HRESIMS analysis and by comparison with data reported in the literature. Tested on STC-1 cells at the concentration of $100 \mathrm{mu} \mathrm{M}$, compounds 7, 11, and 12 increased GLP-1 secretion by 305,218 , and 156\% respectively, compared to control cells, without affecting cell viability.
\end{abstract}

\section{Graphical abstract}
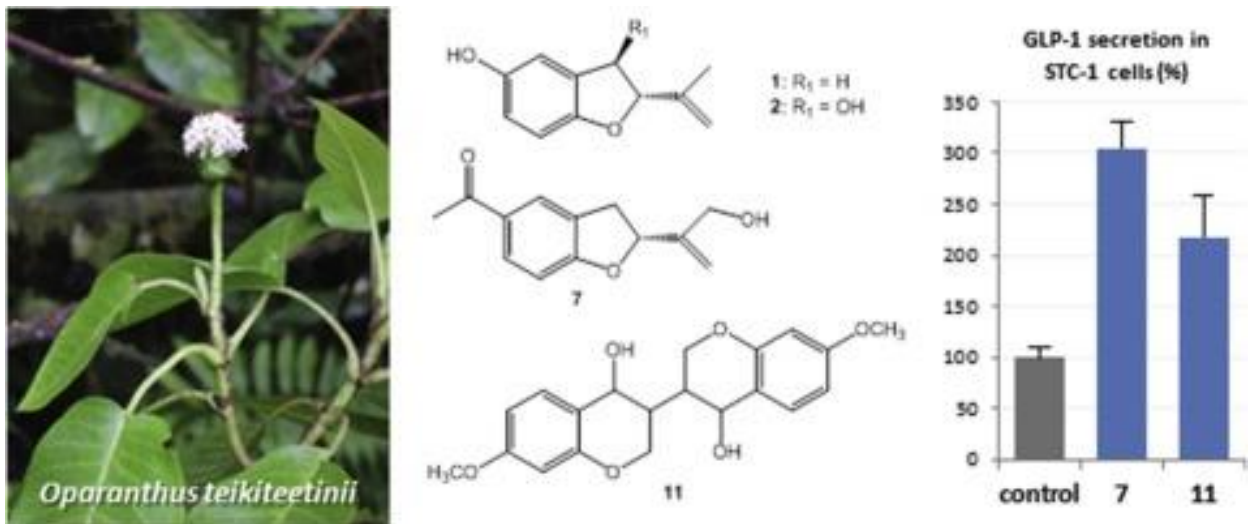


\section{Highlights}

- This is the first report on phytochemistry and bioactivity of Oparanthus teikiteetinii. Two dihydrobenzofuran derivatives (1-2) were identified for the first time. $\rightarrow$ Several compounds stimulate GLP-1 secretion in STC-1 cells without cytotoxicity. 12-hydroxy-tremetone (7) is the most active with a stimulation of $305 \pm 26 \%$.

Keywords : Oparanthus teikiteetinii, Benzofuran derivatives, Coumaran, Sesquiterpene lactones, Glucagon-like peptide-1 secretion 


\section{Introduction}

Oparanthus teikiteetinii (J.Florence \& Stuessy) R.K.Shannon \& W.L.Wagner is a tree endemic to the Marquesas Islands, French Polynesia, which belongs to the Asteraceae family and to the subtribe Coreopsidinae. Firstly described under the genus Bidens (Florence and Stuessy, 1988), it has been recently revised to the genus Oparanthus (Ryding and Bremer, 1992; Shannon and Wagner, 1997). No traditional uses have been reported for this species that has been found only in the restricted area of the Toovi plateau on the island of Nuku Hiva, and no phytochemical nor pharmacological studies have been conducted until now. According to phylogenetic trees, 0 . teikiteetinii is rather closely-related to Fitchia speciosa, endemic to the Cook Islands (Kimball and Crawford, 2004). This latter species was found to contain mainly sesquiterpene lactones, as most of the Asteraceae, and dihydrobenzofuran derivatives (Bohlmann et al., 1980). As part of our continuous efforts to identify natural GLP-1 secretagogues, we decided to evaluate the potential of $O$. teikiteetinii to stimulate the secretion of glucagon-like peptide-1 (GLP-1) in vitro in a mouse intestinal cell culture model. GLP-1 is an intestinally secreted peptide involved in blood glycemia regulation (Nicolaus et al., 2011). As its secretion is impaired in patients with type 2 diabetes, compounds improving GLP-1 secretion levels could therefore represent a novel therapeutic strategy (Nauck et al., 1993; Nauck et al., 1997; Vilsbøll et al., 2001). In our in vitro assay, the EtOAc extract from the leaves of 0 . teikiteetinii increased significantly the extracellular secretion of GLP-1 in STC-1 cells. The phytochemical investigation of this extract led to the isolation of 15 compounds, including mainly benzofuran and benzopyran derivatives (1-11), together with 4 sesquiterpenoids (12-15). All compounds were evaluated for GLP1 secretagogue activity and some of them $(\mathbf{7}, \mathbf{1 1}$, and $\mathbf{1 2})$ were found to be significantly active. This is the first report on phytochemical composition and biological activity of Oparanthus teikiteetinii.

\section{Results and discussion}

The EtOAc extract from the leaves of $O$. teikiteetinii increased the extracellular secretion of GLP-1 in STC-1 cells by $249 \pm 2 \%$ when tested at a concentration of $30 \mu \mathrm{g} / \mathrm{mL}$ (Supplem. S1). This extract was subjected to successive chromatographic separations leading to fifteen compounds (1-15) (Figure 1 and Supplem. S2), including two new dihydrobenzofuranes identified as (2R)-2-(prop-1-en-2-yl)-2,3dihydro-1-benzofuran-5-ol (1) and (2S,3R)-2-(prop-1-en-2-yl)-2,3-dihydro-1-benzofuran-3,5-diol (2). Eight other coumaran derivatives were isolated and identified by careful comparison of their spectral data with those reported in the literature as tremetone (3) (Banskota et al., 1998; Bonner et al., 1961; Lee et al., 2010), 3-hydroxytremetone (4), 6-hydroxytremetone (5), 3,6-diydroxytremetone (6), 12-hydroxytremetone (7), 3-hydroxytremetol (8), megapodiol (9), and 6-hydroxy-megapodiol (10) (Jarvis et al., 1986; Spring et al., 1991). According to optical rotation and comparison with data in literature, all the isolated 2-substituted dihydrobenzofuran derivatives were found to have a $2 R$ 
absolute configuration and the $3-\mathrm{OH}, 2$-substituted derivatives a $2 \mathrm{~S}, 3 \mathrm{R}$ configuration, which is in accordance with previous literature reports (Wang et al., 2016). A bibenzopyran derivative, jasopyran (11), was also obtained (Ahmed et al., 2004), together with four sesquiterpene lactones: costunolide (12) (Rao et al., 1958, 1960), dihydrocostunolide (13), asperilin (14) (Herz and Kagan, 1967; Herz and Viswanathan, 1964), and grandulin (15). The structure of the latter was wrongly reported as a constituent of Inula grandis (Nikonova and Nikonov, 1970; Nikonova and Nikonov, 1972). Therefore, the natural occurrence of grandulin is herein reported for the first time.

Compound $\mathbf{1}$ was isolated as colorless oil. Its UV spectrum presented maxima of absorption at 228 and $300 \mathrm{~nm}$. Its molecular formula was determined to be $\mathrm{C}_{11} \mathrm{H}_{12} \mathrm{O}_{2}$ on the basis of the observed peak at $m / z 177.0909[\mathrm{M}+\mathrm{H}]^{+}$, indicating six degrees of unsaturation. The ${ }^{13} \mathrm{C}$ and ${ }^{1} \mathrm{H}$ NMR data displayed typical signals of a 2,3-dihydrobenzofuran ring, confirmed by HMBC correlations. The proton and carbon signals are shown in Table 1 . The aromatic ring was shown to be hydroxylated in para ( $\delta \mathrm{C}$ 150.9 ), and the furan ring substituted in C-2 ( $\delta C 85.4)$ by a methylethenyl group composed of one olefinic quaternary carbon ( $\delta C 144.7)$, one olefinic methine ( $\delta C 110.4)$, and one methyl $(\delta C 15.9)$. The methylene signal observed in DEPT and ${ }^{1} \mathrm{H}$ spectrum was assigned to position 3 ( $\delta \mathrm{C} 34.8 ; \delta \mathrm{H} \mathrm{3.25}$, dd, $J=15.7,8.3 \mathrm{~Hz} ; 2.96, \mathrm{dd}, J=15.7,8.3 \mathrm{~Hz})$. Thus compound 1 was identified as 2,3-dihydro-2-(1methylethenyl)-5-benzofuranol. This compound has been previously reported as a synthetic intermediate in the synthesis of coumaranol derivatives (Schädel and Habicher, 2002), but is now reported for the first time as a natural product and named oparanol.

Compound $\mathbf{2}$ was obtained as slightly orange oil and presented a UV spectrum similar to the one of compound 1. Its molecular formula was deduced to be $\mathrm{C}_{11} \mathrm{H}_{12} \mathrm{O}_{3}\left(\mathrm{~m} / \mathrm{z}\right.$ 191.0707, $\left.[\mathrm{M}-\mathrm{H}]^{-}\right)$. The ${ }^{1} \mathrm{H}$ and ${ }^{13} \mathrm{C}$ NMR spectra of compound $\mathbf{2}$ were remarkably similar to those of compound $\mathbf{1}$, confirming a 5 hydroxyl-benzofuran skeleton substituted by a methylethenyl group in C-2 (see Table 1 for ${ }^{13} \mathrm{C}$ and ${ }^{1} \mathrm{H}$ data). The downfield values for C-3 ( $\delta C 76.6)$ indicated the presence of an hydroxyl group in position 3 , confirmed by the absence of a methylene signal in the ${ }^{1} \mathrm{H}$ spectrum but the presence of an oxygenated methine signal at $5.02(\mathrm{~d}, J=4.3 \mathrm{~Hz})$. The relative configuration was assumed to be trans on the basis of the small coupling constant observed between $\mathrm{H}-2$ and $\mathrm{H}-3(4.3 \mathrm{~Hz})$, according to the Karplus equation and to literature (Zalkow et al., 1972). Therefore, $\mathbf{2}$ was elucidated as 2,3-dihydro-2(1-methylethenyl)-benzofuran-3,5-diol and named 3-hydroxy-oparanol.

All compounds were evaluated for their capacity to stimulate GLP-1 secretion in an in vitro model of STC-1 cells in culture (Table 2). The dihydrobenzofuran derivative 12-hydroxy-tremetone (7) was found to be the most active resulting in a 3-fold increase in GLP-1 secretion in STC-1 cells (305 \pm 26\%). Jasopyran (11) and costunolide (12) were also found to contribute to the bioactivity of the extract, as they stimulated GLP-1 secretion by $218 \pm 41 \%$ and $156 \pm 39 \%$ respectively. Furthermore, none of the isolated compounds affected STC-1 cells viability at the tested concentration, reinforcing 
their therapeutic potential. However, in order to confirm the potential of $O$. teikiteetinii compounds as antidiabetic agents, further in vitro and in vivo assays are required to identify mechanisms of actions and to assess lack of toxicity. As $O$. teikiteetinii is considered as a threatened species due to its extremely narrow distribution, alternative sourcing is mandatory. Chemical synthesis could be considered thank to the rather simple structure of active constituents (Sangeeta and Deepti, 2017). Also, alternative natural sources could be used. Compound 7, the most active constituent in our bioassay, has been previously reported from various Helichrysum species, already used for essential oil production (Valverde Lopez and Rodriguez Gonzalez, 1971; Zapesochnaya et al., 1990). Supercritical $\mathrm{CO}_{2}$ extraction from Helichrysum italicum flowers can be performed to yield an extract containing up to $23 \%$ of compound 7 (Jerković et al., 2016), providing therefore another source to study in depth its therapeutic potential. This would enable the preservation of biodiversity while contributing to the development of potential new drugs for the management of type 2 diabetes.

\section{Experimental}

\subsection{General experimental procedures}

Optical rotations were measured on a Jasco P-2000 polarimeter $(\lambda 589 \mathrm{~nm}$, path length $1.0 \mathrm{~cm})$. NMR experiments were conducted on a Bruker $500 \mathrm{MHz}$ Avance II spectrometer equipped with a ${ }^{13} \mathrm{C} /{ }^{1} \mathrm{H}$ cryoprobe. HRESIMS analyses were carried out on an Agilent 6520 Q-ToF mass spectrometer. Preparative HPLC was conducted on a Gilson 322 LC system using an Axia Phenomenex C18 column $(100 \mathrm{~mm} \times 21.2 \mathrm{~mm})$. Mobile phase consisted of a mixture of acetonitrile $(\mathrm{ACN})$ and water $\left(\mathrm{H}_{2} \mathrm{O}\right)$ containing $0.05 \% \mathrm{v} / \mathrm{v}$ formic acid at a flow rate of $25 \mathrm{~mL} / \mathrm{min}$. Vacuum liquid chromatography (VLC) was performed using 40-60 $\mu \mathrm{m}$ silica gel (Sigma Aldrich). Sephadex LH-20 (Sigma Aldrich) was used for gel filtration chromatography. Thin-layer chromatography (TLC) was performed on pre-coated silica gel plates (silica gel 60 F254, Merck). HPLC grade solvents were purchased from Sigma Aldrich.

\subsection{Plant material}

Fresh leaves $(1.75 \mathrm{~kg})$ of Oparanthus teikiteetinii were collected in January 2015 in Nuku-Hiva, Marquesas Islands, French Polynesia, and identified by Dr Jean-François Butaud, botanist. The harvesting permit $n^{\circ} 0923$ was delivered from DIREN in November 2014. A voucher specimen (No CM1717_OT 01-2015) is deposited at the herbarium of the University of French Polynesia.

\subsection{Extraction and isolation}

The air dried leaves of Oparanthus teikiteetinii (153.9 g) were crushed and extracted by maceration with EtOAc (100 mL/50 g, $3 \times 3$ hours). The filtrates were combined and evaporated to obtain a crude EtOAc extract $(28.15 \mathrm{~g})$. The EtOAc extract was fractionated using vacuum liquid chromatography 
(150 g of silica $60 \AA, 40-63 \mu \mathrm{m}, 230-400$ mesh), each fraction obtained by eluting with $300 \mathrm{~mL}$ of the following solvents: cyclohexane (c-Hex), c-Hex- $\mathrm{CHCl}_{3}$ (1:1), $\mathrm{CHCl}_{3}, \mathrm{CHCl}_{3}$-EtOAc (75:25), $\mathrm{CHCl}_{3}$-EtOAc (1:1), EtOAc and $\mathrm{CH}_{3} \mathrm{OH}(500 \mathrm{~mL})$ to afford seven fractions; F1 (0.71 g), F2 (0.66 g), F3 (6.86 g), F4 (14.18 g), F5 (2.47 g), F6 (1.09 g), and F7 (2.08 g). F3 (750 mg) was fractionated on Sephadex-LH 20 eluting with $\mathrm{CHCl}_{3} / \mathrm{CH}_{3} \mathrm{OH}(1: 1)$ to obtain twelve sub fractions (F3S1-F3S12). Sub fraction S-10 (62.1 $\mathrm{mg}$ ) was purified by preparative HPLC (20\% ACN during $3 \mathrm{~min}$, to $65 \% \mathrm{ACN}$ in $12 \mathrm{~min}$ ) to yield compound 12 (41.2 mg). Sub fraction S-11 (201.2 mg) was purified in the same conditions to afford compounds 3 (108.3 mg), 5 (24.9 mg), and 12 (40.9 mg). F4 (800 mg) was fractionated using Sephadex $\mathrm{LH}-20 \mathrm{CHCl}_{3} / \mathrm{CH}_{3} \mathrm{OH}$ (1:1) to afford ten main sub fractions (F4S1-F4S10). F4-S9 (402.4 mg) was purified by preparative HPLC ( $20 \% \mathrm{ACN}$ during $3 \mathrm{~min}$, to $65 \% \mathrm{ACN}$ in $12 \mathrm{~min}$ ) to yield compounds 3 (91.9 mg), 12 (109.9 mg), and 13 (6.0 mg). Using the same conditions, compounds 1 (2.5 mg), 3 $(64.8 \mathrm{mg}), \mathbf{5}(8.9 \mathrm{mg}), \mathbf{8}(2.5 \mathrm{mg})$, and $12(10.7 \mathrm{mg})$ were obtained from sub fraction F4-S10 (133.9 $\mathrm{mg}$ ). F5 (700 mg) was also chromatographed on Sephadex-LH 20 column eluting with $\mathrm{CHCl}_{3} / \mathrm{CH}_{3} \mathrm{OH}$ (30:70) to obtain eight sub fractions (F5S1-F5S8). Sub fraction F5-S7 (129.6 mg) was further purified by preparative HPLC ( $20 \% \mathrm{ACN}$ during $3 \mathrm{~min}$, to $65 \% \mathrm{ACN}$ in $12 \mathrm{~min}$ ) to afford compounds 7 (1.0 $\mathrm{mg}$ ), $\mathbf{8}(5.5 \mathrm{mg}), \mathbf{1 1}(1.6 \mathrm{mg}), \mathbf{6}(1.0 \mathrm{mg})$, and $\mathbf{1 4}(2.6 \mathrm{mg})$. Sub fraction F5-S8 (38.7 mg) was also purified on Axia column (20\% ACN during $3 \mathrm{~min}, 20$ to $65 \%$ in $19 \mathrm{~min}$, then 65 to $80 \%$ in $4 \mathrm{~min}$ ) to yield 15 (17.0 $\mathrm{mg}), 9(4.1 \mathrm{mg})$, and $8(2.5 \mathrm{mg})$. F6 $(800 \mathrm{mg})$ was first fractionated on Sephadex LH-20 eluting with $\mathrm{CHCl}_{3} / \mathrm{CH}_{3} \mathrm{OH}(30: 70)$ to obtain seven sub fractions (F6S1-F6S7). Sub fraction F6S6 (120 mg) was subjected to preparative HPLC ( 35 to $65 \%$ ACN in $13 \mathrm{~min}$, then to $100 \%$ ACN in $5 \mathrm{~min}$, flow rate 15 $\mathrm{mL} / \mathrm{min}$ ) to afford compounds $2(1.0 \mathrm{mg}), 4(8.0 \mathrm{mg})$, and 9 (23.1 mg). Sub fraction F6S7 (20.2 mg) led to compound 10 (1.1 mg) after preparative HPLC.

\subsection{1. (2R)-2-(prop-1-en-2-yl)-2,3-dihydro-1-benzofuran-5-ol (1)}

Colorless oil; $[\alpha]_{D}^{20}-102.5$ (c $\left.0.18, \mathrm{MeOH}\right) ;$ UV (nm): 203, 228, 300; HRESIMS m/z $177.0909[\mathrm{M}+\mathrm{H}]^{+}$, (calcd error $-0.6 \mathrm{ppm}$ ); ${ }^{1} \mathrm{H}$ NMR and ${ }^{13} \mathrm{C}$ NMR data: see Table 1.

\subsection{2. (2S,3R)-2-(prop-1-en-2-yl)-2,3-dihydro-1-benzofuran-3,5-diol (2)}

Slightly orange oil; $[\alpha]_{D}^{20}-97.2$ (c 0.18, MeOH); UV (nm): 203, 228, 302; HRESIMS m/z 191.0707 [M-H] , (calcd error -3.5 ppm); ${ }^{1} \mathrm{H}$ NMR and ${ }^{13} \mathrm{C}$ NMR data: see Table 1.

3.3.3. (3aR,8R,8aR,9aR)-8-hydroxy-5,8a-dimethyl-3-methylene-3a,4,4a,7,8,8a,9,9a-octahydronaphtho[2,3-b]furan-2(3H)-one (15) 
White amorphous powder; $[\alpha]_{D}^{20}+45.9$ (c $0.10, \mathrm{MeOH}$ ); UV (nm): $215 ; \mathrm{HRESIMS} \mathrm{m} / \mathrm{z} 249.1480$ $[\mathrm{M}+\mathrm{H}]^{+}$, (calcd error $\left.-2.1 \mathrm{ppm}\right) ;{ }^{1} \mathrm{H}$ NMR and ${ }^{13} \mathrm{C}$ NMR data: see Table 1.

\subsection{Bioassays}

\subsubsection{GLP-1 secretion assay}

GLP-1 secretion assays were carried out as described previously (Tsoukalas et al., 2016). Briefly, STC1 cells were cultured at $37^{\circ} \mathrm{C}$ under a $5 \% \mathrm{CO}_{2}$ atmosphere in high glucose $(4.5 \mathrm{~g} / \mathrm{L})$ complete Dulbecco's modified Eagle's medium (DMEM, supplemented with $10 \%$ non-heat-inactivated fetal bovine serum (FBS), penicillin $100 \mathrm{IU} \mathrm{mL}$, and streptomycin $100 \mathrm{IU} \mathrm{mL} \mathrm{L}^{-1}$ ). Cells were passed at subconfluency every 3-4 days. Twenty-four hours prior induction, $10^{4}$ cells per well in $100 \mu \mathrm{L}$ complete low glucose $(1 \mathrm{~g} / \mathrm{L}$ ) DMEM were seeded in a 96-well plate. Prior to treatment, cells were washed two times with HBSS (Thermo Fischer 14025092), after addition of $100 \mu \mathrm{L}$ HBSS they were returned back in the incubator for $30 \mathrm{~min}$. The samples DMSO stock solutions were diluted at 100 $\mu \mathrm{M}$ in HBSS containing a constant DMSO concentration of $1 \%$. Finally, $125 \mu \mathrm{L}$ of the diluted solutions were applied to the cells for 2 hours at $37^{\circ} \mathrm{C}$ in a $5 \% \mathrm{CO}_{2}$ atmosphere. The GLP-1 content of $100 \mu \mathrm{L}$ of the cell supernatant was then quantified in an ELISA assay (Merck Millipore, EGLP-35K) according to the manufacturer instructions. For each molecule the assay was performed in quadruplicate and results expressed as the percentage of the GLP-1 content secreted by cells treated with HBSS containing only $1 \%$ DMSO. For the statistical analysis, a one-way ANOVA with post hoc Dunnett test was performed ( $\left.* p_{\mathrm{adj}} \leq 0.05 ; * * * \mathrm{p}_{\mathrm{adj}} \leq 0.001\right)$.

\subsubsection{Cytotoxicity assay}

For the image cytometry assay, the STC-1 cells after treatment with the molecules were incubated during 20 minutes with DMEM complete medium containing propidium iodide, Hoechst reagent, and calcein (1 $\mu \mathrm{M}$ each). After incubation, pictures of each well were taken with a Celigo Imaging Cytometer (Nexcelom Bioscience) at visible and fluorescent light and processed with the Celigo program in order to quantify the percentage of viable cells.

\section{Acknowledgments}

This work was financially supported by the Foundation for the Development of the Chemistry of Natural Products and their Applications (CNRS/Academy of Sciences in Paris). We gratefully acknowledge Nicolas Humbert, Dr Christian D. Muller, and Dr Julien Godet for assistance with microplate reading, image cytometry, and statistical analysis, respectively. 


\section{References}

Ahmed, B., Al-Howiriny, T. A., Al-Rehaily, A. J., Mossa, J. S., 2004. Two germacrane sesquiterpenes and a bibenzopyran from Jasonia montana. J. Saudi Chem. Soc. 8, 105-114.

Banskota, A. H., Tezuka, Y., Prasain, J. K., Matsushige, K., Saiki, I., Kadota, S., 1998. Chemical constituents of Brazilian propolis and their cytotoxic activities. J. Nat. Prod. 61, 896-900.

Bohlmann, F., Zdero, C., King, R. M., Robinson, H., 1980. New sesquiterpene lactones and other constituents from Fitchia speciosa. Phytochemistry 19, 1141-1143.

Bonner, W. A., De, G. J. I., Bowen, D. M., Shah, V. R., 1961. Toxic constituents of white snakeroot. Tetrahedron Lett. 417-420.

Florence, J., Stuessy, T. F., 1988. Sertum polynesicum 3 : un Bidens (Asteraceae) nouveau de l'île de Nukuhiva (Marquises, Polynésie Française). Bull. Mus. Natl. Hist. Nat., B, Adansonia 10, 121-125.

Herz, W., Kagan, H. B., 1967. Determination of the absolute configuration of hydroxylated sesquiterpene lactones by Horeau's method of asymmetric esterification. J. Org. Chem. 32, 216-218.

Herz, W., Viswanathan, N., 1964. Constituents of Iva species. II. The structures of asperilin and ivasperin, two new sesquiterpene lactones. J. Org. Chem. 29, 1022-1026.

Jarvis, B. B., Pena, N. B., Cömezóg̀lu, S. N., Rao, M. M., 1986. Non-trichothecenes from Baccharis megapotamica. Phytochemistry 25, 533-535.

Jerković, I., Rajić, M., Marijanović, Z., Bilić, M., Jokić, S., 2016. Optimization of supercritical $\mathrm{CO}_{2}$ extraction of dried Helichrysum italicum flowers by response surface methodology: GC-MS profiles of the extracts and essential oil. Sep. Sci. Technol. (Philadelphia, PA, U. S.) 51, 2925-2931.

Kimball, R. T., Crawford, D. J., 2004. Phylogeny of Coreopsideae (Asteraceae) using ITS sequences suggests lability in reproductive characters. Mol. Phylogenet. Evol. 33, 127-139.

Lee, S. T., Davis, T. Z., Gardner, D. R., Colegate, S. M., Cook, D., Green, B. T., Meyerholtz, K. A., Wilson, C. R., Stegelmeier, B. L., Evans, T. J., 2010. Tremetone and structurally related compounds in white snakeroot (Ageratina altissima): A plant associated with trembles and milk sickness. J. Agri. Food Chem. 58, 8560-8565.

Nauck, M. A., Kleine, N., Orskov, C., Holst, J. J., Willms, B., Creutzfeldt, W., 1993. Normalization of fasting hyperglycaemia by exogenous glucagon-like peptide 1 (7-36 amide) in type 2 (non-insulindependent) diabetic patients. Diabetologia 36, 741-744.

Nauck, M. A., Holst, J. J., Willms, B., Schmiegel, W., 1997. Glucagon-like peptide 1 (GLP-1) as a new therapeutic approach for Type 2-diabetes. Exp. Clin. Endocrinol. Diabet. 105, 187-195.

Nicolaus, M., Brodl, J., Linke, R., Woerle, H. J., Goke, B., Schirra, J., 2011. Endogenous GLP-1 regulates postprandial glycemia in Humans: relative contributions of insulin, glucagon, and gastric emptying. J. Clin. Endocrinol. Metab. 96, 229-236. 
Nikonova, L. P., Nikonov, G. K., 1970. Grandulin and grandicin - new sesquiterpene lactones from Inula grandis. Khim. Prir. Soed. 6, 133-134.

Nikonova, L. P., Nikonov, G. K., 1972. Structure of grandicin and grandulin. Khim. Prir. Soed. 5, 679680.

Rao, A. S., Kelkar, G. R., Bhattacharyya, S. C., 1958. Costunolide, a new sesquiterpene lactone from costus root oil. Chem. Ind. 1359-1360.

Rao, A. S., Kelkar, G. R., Bhattacharyya, S. C., 1960. Terpenoids. XXI. Structure of costunolide, a new sesquiterpene lactone from Costus root oil. Tetrahedron 9, 275-283.

Ryding, O., Bremer, K., 1992. Phylogeny, distribution, and classification of the Coreopsideae (Asteraceae). Syst. Bot. 649-659.

Sangeeta, B., Deepti, R., 2017. Synthetic routes and biological activities of benzofuran and its derivatives: a review. Lett. Org. Chem. 14, 381-402.

Schädel, U., Habicher, W. D., 2002. Synthesis of coumaran-5-ols - new model compounds for bioantioxidants. Heterocycles 57, 1049-1055.

Shannon, R. K., Wagner, W. L., 1997. Oparanthus (Asteraceae, subtribe Coreopsidinae) revisited. Allertonia 7, 273-295.

Spring, O., Vargas, D., Fischer, N. H., 1991. Sesquiterpene lactones and benzofurans in glandular trichomes of three Pappobolus species. Phytochemistry 30, 1861-1867.

Tsoukalas, M., Muller, C. D., Lobstein, A., Urbain, A., 2016. Pregnane glycosides from Cynanchum marnierianum stimulate GLP-1 secretion in STC-1 cells. Planta Med. 82, 992-999.

Valverde Lopez, S., Rodriguez Gonzalez, B., 1971. Benzofuran derivative isolated from Helichrysum stoechas. An. Quim. 67, 879-885.

Vilsbøll, T., Krarup, T., Deacon, C. F., Madsbad, S., Holst, J. J., 2001. Reduced postprandial concentrations of intact biologically active glucagon-like peptide 1 in type 2 diabetic patients. Diabetes 50, 609-613.

Wang, Y.-M., Zhao, J.-Q., Zhou, S.-Y., Yang, J.-L., Yao, X.-J., Tao, Y.-D., Mei, L.-J., Shi, Y.-P., 2016. New sesquiterpenes and benzofuran derivatives from the aerial parts of Asterothamnus centrali-asiaticus. Tetrahedron 72, 4910-4917.

Zalkow, L. H., Keinan, E., Steindel, S., Kalyanaraman, A. R., Bertrand, J. A., 1972. On the absolute configuration of toxol at C-3. Vicinal H-H coupling constants in 2-alkyl-3-hydroxydihydrobenzofurans. Tetrahedron Lett. 13, 2873-2876.

Zapesochnaya, G. G., Dzyadevich T. V., Karasartov B. S. Phenolic compounds of Helichrysum italicum. Chem. Nat. Compd. 1990; 26: 342-343. 
Table $1 .{ }^{1} \mathrm{H}$ and ${ }^{13} \mathrm{C}$ NMR data for compounds $\mathbf{1}, \mathbf{2}$, and 15 (methanol- $d_{4}, \delta$ in ppm, $J$ in $\mathrm{Hz}, 500 \mathrm{MHz}$ for ${ }^{1} \mathrm{H}$ NMR, $125 \mathrm{MHz}$ for ${ }^{13} \mathrm{C}$ NMR).

\begin{tabular}{|c|c|c|c|c|c|c|}
\hline \multirow[b]{2}{*}{ position } & \multicolumn{2}{|r|}{1} & \multicolumn{2}{|r|}{2} & \multicolumn{2}{|r|}{15} \\
\hline & $\delta_{c}$ & $\delta_{H}$ & $\delta_{c}$ & $\delta_{H}$ & $\delta_{c}$ & $\delta_{\mathrm{H}}$ \\
\hline 1 & & & & & 121.4 & $5.38(\mathrm{~m})$ \\
\hline 2 & 85.4 & $5.07(t, 8.3)$ & 93.4 & $4.75(\mathrm{~d}, 4.3)$ & 32.1 & $\begin{array}{l}2.38(\mathrm{~m}) \\
2.33(\mathrm{~m})\end{array}$ \\
\hline 3 & 34.8 & $\begin{array}{l}3.25(\mathrm{dd}, 15.7,8.3) \\
2.96(\mathrm{dd}, 15.7,8.3)\end{array}$ & 76.6 & $5.02(\mathrm{~d}, 4.3)$ & 77.4 & $3.64(\mathrm{~m})$ \\
\hline 4 & 113.6 & $6.63(d, 1.5)$ & 111.6 & $6.81(\mathrm{~m})$ & 40.7 & - \\
\hline 5 & 150.9 & - & 151.2 & - & 34.2 & $\begin{array}{l}2.05(\mathrm{~m}) \\
1.35(\mathrm{~m})\end{array}$ \\
\hline 6 & 111.6 & $6.52(\mathrm{~m})$ & 116.6 & $6.69(\mathrm{~m})$ & 82.1 & $4.04(t)$ \\
\hline 7 & 108.3 & $6.51(\mathrm{~m})$ & 109.4 & $6.66(\mathrm{~m})$ & 51.0 & 2.59 (br s) \\
\hline 8 & 152.9 & - & 153.2 & - & 20.7 & $\begin{array}{l}2.12(\mathrm{~m}) \\
1.68(\mathrm{~m})\end{array}$ \\
\hline 9 & 127.3 & - & 128.7 & - & 50.8 & $2.42(\mathrm{br} \mathrm{d}, 11.9)$ \\
\hline 10 & 144.7 & - & 142.7 & - & 133.2 & - \\
\hline 11 & 110.4 & $\begin{array}{l}5.04(s) \\
4.86(s)\end{array}$ & 110.7 & $\begin{array}{c}5.06(\mathrm{~m}) \\
4.89 \text { (overlap) }\end{array}$ & 139.6 & - \\
\hline 12 & 15.9 & $1.74(\mathrm{~s})$ & 16.2 & 1.79 (s) & 171.4 & - \\
\hline 13 & & & & & 115.6 & $\begin{array}{l}6.03(\mathrm{~s}) \\
5.52(\mathrm{~s})\end{array}$ \\
\hline 14 & & & & & 22.2 & $1.84(\mathrm{~s})$ \\
\hline 15 & & & & & 9.96 & $0.89(\mathrm{~s})$ \\
\hline
\end{tabular}


Table 2. Glucagon-like peptide-1 secretagogue activity and cell viability induced by compounds 1-15 (tested at $100 \mu \mathrm{M}$ on STC-1 cells).

\begin{tabular}{rcc}
\hline Compound & $\begin{array}{c}\text { GLP-1 secretion } \\
\text { stimulation (\%) }\end{array}$ & Cell viability (\%) \\
\hline control & $100 \pm 10$ & $96 \pm 1$ \\
$\mathbf{7}^{\mathrm{a}}$ & $305 \pm 26$ & $96 \pm 1$ \\
$\mathbf{1 1}^{\mathbf{a}}$ & $218 \pm 41$ & $97 \pm 1$ \\
$\mathbf{1 2}^{\mathbf{b}}$ & $156 \pm 39$ & $94 \pm 1$ \\
$\mathbf{1 5}$ & $145 \pm 15$ & $96 \pm 1$ \\
$\mathbf{1}$ & $121 \pm 9$ & $97 \pm 1$ \\
$\mathbf{1 0}$ & $109 \pm 11$ & $95 \pm 1$ \\
$\mathbf{1 4}$ & $104 \pm 6$ & $97 \pm 1$ \\
$\mathbf{4}$ & $104 \pm 16$ & $91 \pm 2$ \\
$\mathbf{1 3}$ & $102 \pm 20$ & $95 \pm 2$ \\
$\mathbf{3}$ & $101 \pm 20$ & $96 \pm 1$ \\
$\mathbf{9}$ & $100 \pm 16$ & $95 \pm 1$ \\
$\mathbf{6}$ & $94 \pm 9$ & $96 \pm 1$ \\
$\mathbf{2}$ & $93 \pm 25$ & $91 \pm 2$ \\
$\mathbf{8}$ & $91 \pm 13$ & $96 \pm 1$ \\
$\mathbf{5}$ & $81 \pm 9$ & $97 \pm 1$ \\
\hline
\end{tabular}

Data are expressed as the mean \pm SD of four independent experiments.

a *** $p_{\text {adj }}<0.001$

$\mathrm{b} * \quad \mathrm{p}_{\mathrm{adj}}<0.05$ 
Figure 1. Structures of compounds 1-2 and 15. 


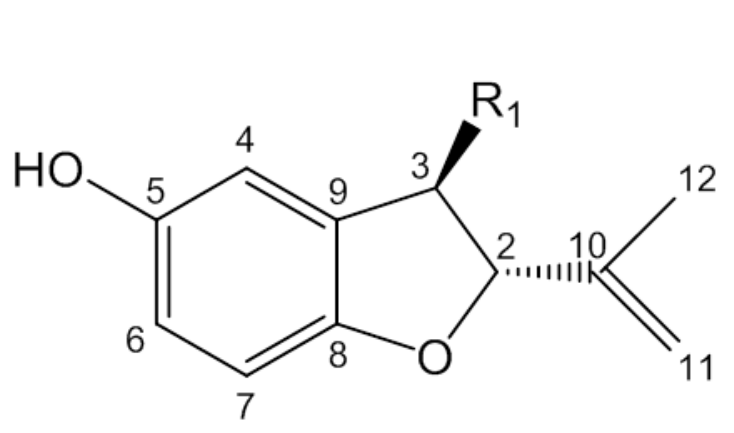

1: $\mathrm{R}_{1}=\mathrm{H}$

2: $\mathrm{R}_{1}=\mathrm{OH}$

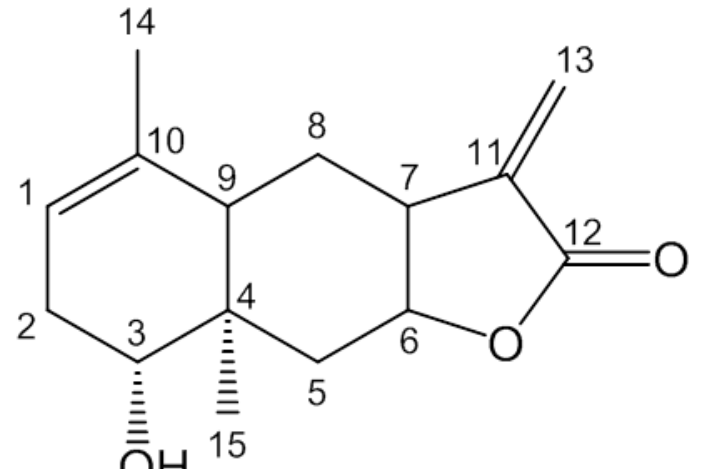

15 


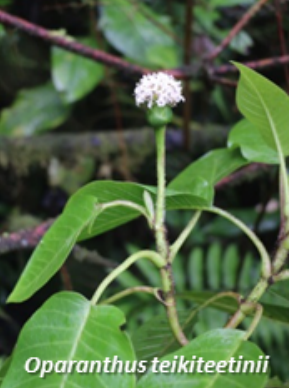

GLP-1 secretion in STC-1 cells (\%)

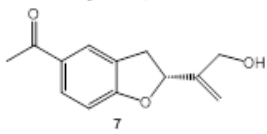

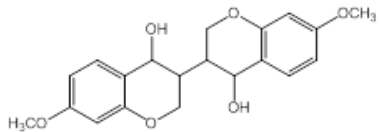

1: $R_{1}=H$

2: $\mathrm{R}_{1}=\mathrm{OH}$

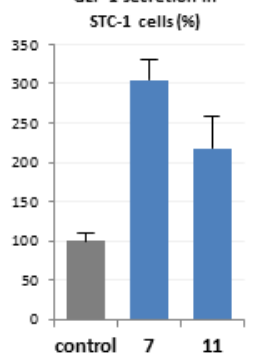

